\title{
HADAPI INFEKSI NOSOKOMIAL DENGAN HAND HYGIENE AKIBAT KECELAKAAN KERJA PERAWAT DALAM PEMBERIAN ASUHAN KEPERAWATAN DI RUMAH SAKIT
}

\author{
NOVITA SARI \\ novitampii1212@gmail.com
}

\begin{abstract}
ABSTRAK
Infeksi nosokomial yang terjadi pada pasien di rumah sakit karena infeksi yang berhubungan dengan pelayanan di fasilitas kesehatan dan juga rumah sakit sebagai fasilitas pelayanan kesehatan mempunyai peranan penting dalam memberikan pelayanan kesehatan yang bermutu, efektif dan efisien yang menjamin patient safety sesuai dengan standar yang telah ditentukan. Salah satu indikator patient safety adalah pengurangan resiko infeksi terkait dengan pelayanan kesehatan. Infeksi nosokomial yang saat ini dikenal sebagai Healthcare Associated Infections (HAIs) adalah infeksi yang berhubungan dengan pelayanan di fasilitas kesehatan. Hand hygiene menjadi salah satu langkah yang efektif untuk memutuskan rantai transmisi infeksi, sehinga insidensi nosokomial dapat berkurang. Pencegahan dan pengendalian infeksi wajib dilakukan oleh perawat, dokter dan seluruh orang yang terlibat dalam perawatan pasien (Fauziah \& Rachmawati, 2018). Tujuan penilitian adalah untuk mengetahui pencegahan dan pengendalian infeksi nosokomial di rumah sakit. Metode yang digunakan yaitu dengan menggunakan metode deskriptif dengan pendekatan kualitatif. Adapun sumber yang digunakan dalam literature ini menggunakan sumber dari buku teks dan jurnal yang diterbitkan pada 8 tahun terakhir.
\end{abstract}

Kata kunci : infeksi, nosokomial, hand, hygiene dan keperawatan.

\section{LATAR BELAKANG}

Keselamatan dan kesehatan kerja adalah upaya untuk memberikan jaminan keselamatan dan meningkatkan derajat kesehatan para pekerja atau buruh dengan cara pencegahan kecelakaan dan penyakit akibat kerja, pengendalian bahaya di tempat kerja, promosi kesehatan, pengobatan dan rehabilitasi (Menkes, 2007).

Infeksi nosokomial yang saat ini dikenal sebagai Healthcare Associated Infections (HAIs) adalah infeksi yang berhubungan dengan pelayanan di fasilitas kesehatan. Infeksi nosokomial yang terjadi pada 
pasien, baru bisa dikategorikan apabila saat pasien mulai dirawat di rumah sakit tidak didapatkan infeksi atau tanda-tanda klinik dari infeksi, dan tidak sedang dalam masa inkubasi dari infeksi. Rumah sakit sebagai fasilitas pelayanan kesehatan mempunyai peranan penting dalam memberikan pelayanan kesehatan yang bermutu, efektif dan efisien yang menjamin patient safety sesuai dengan standar yang telah ditentukan. Salah satu indikator patient safety adalah pengurangan resiko infeksi terkait dengan pelayanan kesehatan.

Hand hygiene menjadi salah satu langkah yang efektif untuk memutuskan rantai transmisi infeksi, sehinga insidensi nosokomial dapat berkurang. Pencegahan dan pengendalian infeksi wajib dilakukan oleh perawat, dokter dan seluruh orang yang terlibat dalam perawatan pasien (Fauziah \& Rachmawati, 2018).

Keselamatan Kerja adalah keselamatan yang bertalian dengan mesin, pesawat, alat kerja, bahan, dan proses pengolahannya, landasan tempat kerja dan lingkungannya serta cara-cara melakukan pekerjaan. Keselamatan Kerja memiliki sifat yaitu sasarannya lingkungan kerja dan bersifat teknik. Kejadian infeksi nosokomial dipengaruhi oleh pengetahuan dan sikap perawat. Pengetahuan yang baik akan mengurangi kejadian infeksi nosokomial dirumah sakit.
Penyakit karena kerja adalah seuatu kendala pada tingkat keamanan dalam kerja, dalam perihal ini memerlukan usaha pencegahan, baik untuk keselamatan ataupun kesehatan beberapa pekerja yang berada di lingkungan rumah sakit. Penyakit karena kerja atau terkait dengan pekerjaan bisa dikarenakan oleh pemajanan di lingkungan kerja dengan terus menerus setiap hari.

Pengetahuan perawat dalam mengidentifikasi infeksi terkait pelayanan kesehatan atau biasa disebut dengan Healthcare-Associated Infections (HAIs) diperlukan untuk mempermudah pelaksanaan surveilans, selain itu juga dibutuhkan aplikasi yang mempermudah pengumpulan data surveilans, salah satunya epi info.

Untuk menghadapi perihal ini, maka langkah awal yang terpenting ialah pengenalan/identifikasi bahaya yang dapat muncul serta dievaluasi, lalu dikerjakan usaha pengendalian lewat cara melihat serta mengenal (walk through inspections).

Kemungkinan petugas rumah sakit pada gangguan kesehatan serta kecelakaan kerja biasanya dikarenakan oleh perilaku petugas dalam kepatuhan melakukan tiap-tiap mekanisme pada kewaspadaan. Lihat hal diatas tentu saja kita perlu mengerti jika dalam cakupan pekerjaan di bagian 
kesehatan memiliki banyak resiko pada kesehatan pekerja. Tenaga kerja (tenaga medis serta non medis) yang berefek pada penyakit karena kerja di dalam rumah sakit diantaranya:

Jenis cidera akibat kecelakaan kerja dan tingkat keparahan yang ditimbulkan membuat perusahaan melakukan pengklasifikasian jenis cidera akibat kecelakaan. Tujuan pengklasifikasian ini adalah untuk pencatatan dan pelaporan statistik kecelakaan kerja. Banyak standar referensi penerapan yang digunakan berbagai oleh perusahaan, salah satunya adalah standar Australia.

\section{METODE}

Penulisan ini adalah Literature Riview, dimana ini menganalisis artikel dan jurnal yang relevan dan juga berfokus pada tema yaitu "Penyakit akibat kerja pada perawat: Penyakit menular \& tidak menular, Penyakit atau cedera akibat kecelakaan kerja pada perawat" serta pada kajian ini adalah metode kualitatif yang memberikan penjelasan dengan menggunakan analisis. Adapun sumber yang digunakan dalam literature ini menggunakan sumber dari buku teks dan jurnal yang diterbitkan pada 8 tahun terakhir.

\section{HASIL}

Sebagian besar perawat mengalami peningkatan pengetahuan dalam mengidentifikasi HAIs, Berdasarkan hasil observasi terhadap fivemoment hand hygiene yang dilakukan menunjukan bahwa tingkat penerapan five moment hand hygieneyang dilakukan oleh responden pada setiapmoment masih semua responden (10\%)melakukan kegiatan hand hygiene padamoment setelah kontak dengan cairan tubuhpasien dan sesudah kontak dengan pasien.Momen-momen pelaksanan hand hygiene pada penelitan ini kurang diperhatikan. Perawat kurang memperhatikan momen hand hygiene sebelum kontak dengan pasien dan lebih sering mencuci tangan setelah menangani pasien.

Berdarkan penelitan Fauzia dan Rahmawati (2018) menyatakan bahwa salah satu faktor individu yang berpengaruh paling besar adalah pengetahuan perawat, dimana semakin tingi pengetahuan perawat maka semakin tingi juga sikap perawat dalam penerapan hand hygiene. Sikap dan perilaku perawat merupakan salah satu faktor yang mempunyai pengaruh besar terhadap kesehatan perawat dalam pencegahan terjadinya infeksi nosokomial. Perawat memilki andil yang besar terhadap terjadinya infeksi nosokomial karena perawat berinteraksi secara langsung dengan pasien selama 24 jam. 
Salah satu upaya pencegahan infeksi nosokomial dengan melakukan hand hygiene Kasus infeksi nosokomial pada salah satu rumah sakit di wilayah pekanbaru kasus phlebitis pada tahun 2018 sebanyak $6.55 \%$. hal itu berkaitan dengan motivasi dan kepatuhan perawat dalam melakukan hand hygiene namun pada kenyataannya kepatuhan dalam melaksanakan hand hygiene oleh perawat hanya mencapai sekitar $56.3 \%$.

Salah satu upaya pencegahan infeksi nosokomial dengan melakukan hand hygiene. Hand hygiene menurut Persatuan Pengendalian Infeksi Indonesia yaitu suatu prosedur tindakan membersihkan tangan dengan menggunakan sabun atau antiseptik di bawah air mengalir atau dengan menggunakan handscrub yang bertujuan untuk menghilangkan kotoran dari kulit secara mekanis dan mengurangi jumlah mikroorganisme (Perdalin, 2010). Hand hygiene merupakan ukuran yang paling penting dalam tindakan pencegahan karena lebih efektif dan biaya rendah, diperkirakan dengan melakukan hand hygiene dapat pengurangan dampak terhadap infeksi nosokomial sebesar 50\% (Madrazo,2009).

Angka kejadian infeksi nosokomial di rumah sakit di seluruh dunia mencapai $9 \%$ atau kurang lebih 1,40 juta pasien yang dirawat inap terkena infeksi nosokomial. Hasil penelitian yang dilakukan oleh WHO mengenai infeksi nosokomial diperoleh sekitar 8,70\% dari 55 rumah sakit di 14 negara di Eropa, Timut Tengah, Asia Tenggara dan Pasifik.

Kejadian infeksi nosokomial menyebabkan mutu pelayanan yang tidak optimal, sehingga diperlukan tindakan yang tepat dalam mencegah ataupun mengurangi angka kejadian infeksi nosokomial (Zulkarnain, 2018).Hasil penelitian yang diperoleh berdasarkan usia dari bidan berusia 25-30 tahun sebanyak 23 orang $(74,2 \%)$. Usia dapat mempengaruhi daya tangkap dan pola pikir dari seseorang. Semakin bertambahnya usia maka semakin berkembangnya daya tangkap dan pola pikir dari individu tersebut, sehingga pengetahuan yang diperoleh semakin baik (Fitriana, Pratiwi, \& Sutanto, 2015).

Dalam upaya penerapan peningkatakan keselamatan dan kesehatan pasien, maka perawat harus melakukan pencegahaan agar infeksi tidak terjadi kepada pasien. Pencegahan dari infeksi nosokomial ini diperlukan suatu rencana yang terintegrasi, monitoring dan program yang termasuk: Membatasi transmisi organisme dari atau antar pasien dengan cara mencuci tangan dan penggunaan sarung tangan, 5 tindakan septik dan aseptik, sterilisasi dan disinfektan, mengontrol resiko penularan dan lingkungan, melindungi pasien dengan penggunaan antibiotika yang adekuat, 
nutrisi yang cukup, dan vaksinasi, membatasi resiko infeksi endogen dengan meminimalkan prosedur invasive, pengawasan infeksi, identifikasi penyakit dan mengontrol penyebarannya. Pengawasan instrumen yang sering digunakan Rumah Sakit, memperbaiki ketahanan tubuh.

\section{PEMBAHASAN}

Infeksi nosokomial yang terjadi pada pasien, baru bisa dikategorikan apabila saat pasien mulai dirawat di rumah sakit tidak didapatkan infeksi atau tanda-tanda klinik dari infeksi, dan tidak sedang dalam masa inkubasi dari infeksi. Rumah sakit sebagai fasilitas pelayanan kesehatan mempunyai peranan penting dalam memberikan pelayanan kesehatan yang bermutu, efektif dan efisien yang menjamin patient safety sesuai dengan standar yang telah ditentukan.

World Health Organization(WHO) mendeklarasikan program keselamatan pasien dengan mencetuskan Global Patient Safety Challenge "clean care is safe care", serta meluncurkan Save Lives: Clean Your Hands dengan strategi 5 momenthand hygiene (My Five Moments for Hand hygiene) yaitu sebelum kontak dengan pasien, sebelum melakukan tindakan aseptik, setelah terpapar dengan cairan pasien, setelah kontak dengan pasien, setelah kontak dengan lingkungan sekitar pasien".

Terkait perawatan kesehatan atau "Healthcare Associated Infections" (HAIs), yang juga disebut sebagai infeksi "Nosokomial" atau "Rumah Sakit", merupakan infeksi yang terjadi pada pasien selama perawatan di rumah sakit atau fasilitas perawatan.

Pelaksanaan hand hygiene sangat penting dilakukan karena ketidakpatuhan dapat menimbulkan dampak antara lain:

(1) Terhadap pasien, dapat memperpanjang hari rawatan dengan penambahan diagnosa sehingga dapat menyebabkankematian;

(2) Terhadap pengunjung, dapat menularkan kepada orang lain setelah meninggalkan rumah sakit;

(3) Bagi perawat, akan menjadi barier (pembawa kuman) yang menularkan kepada pasien lain dan diri sendiri;

(4) Bagi rumah sakit, menurunkan mutu pelayanan rumah sakit hingga pencabutan ijin operasional rumah sakit. Untuk menjaga keselamatan pasien, pengunjung, perawat dan meningkatkan mutu rumah sakit.

Motivasi merupakan proses mempengaruhi atau mendorong dari luar terhadap seseorang atau kelompok kerja agar mereka mau melaksanakan sesuatu yang telah 
ditetapkan. Sedangkan menurut Liang Gie dalam Samsudin menyatakan bahwa motivasi adalah pekerjaan yang dilakukan oleh manajer dalam memberikan inspirasi, semangat dan dorongan kepada orang lain, dalam hal ini karyawannya, untuk mengambil tindakantindakan tertentu (Andriyani, 2015).

Berdasarkan uraian diatas maka dapat disimpulkan bahwa ada hubungan yang bermakna antara motivasi perawat dengan kepatuhan melakukan hand hygiene sebagai tindakan pencegahan infeksi nosokomial. Motivasi yang tinggi yang dimiliki oleh perawat maka akan meningkatkan kepatuhan perawat dalam melakukan hand hygiene.

Komponen utama standar pencegahan dan pengendalian infeksi nosokomial dalam tindakan operasional mencakup kegiatan sebagai berikut:

1. Mencuci tangan Mencuci tangan sebaiknya dilakukan pada air yang mengalir dan dengan sabun yang digosokkan selama 15 sampai 20 detik. Mencuci tangan dengan sabun biasa dan air bersih adalah sama efektifnya mencuci tangan dengan sabun antimikroba. Ada beberapa kondisi yang mengharuskan petugas kesehatan menggunakan sabun antiseptik ini, yaitu saat akan melakukan tindakan invasif, sebelum kontak dengan pasien yang dicurigai mudah terkena infeksi (misalnya: bayi yang baru lahir dan pasien yang dirawat di ICU).

2. Menggunakan alat pelindung diri/APD seperti: sarung tangan, masker, pelindung wajah, kacamata dan apron pelindung. Alat pelindung diri yang paling baik adalah yang terbuat dari bahan yang telah diolah atau bahan sintetik yang tidak tembus oleh cairan.

3. Praktik keselamatan kerja Praktik keselamatan kerja berhubungan dengan pemakaian instrumen tajam seperti jarum suntikndari menutup kembali jarum suntik yang telah digunakan. Bila terpaksa dilakukan, maka gunakan teknik satu tangan untuk menutup jarum, hindari melepas jarum yang telah digunakan dari spuit sekali pakai, hindari membengkokkan, menghancurkan atau memanipulasi jarum suntik dengan tangan serta masukkan instrumen tajam ke dalam wadah yang tahan tusukkan dan tahan air.

4. Perawatan pasien rawatan pasien yang sering dilakukan meliputi tindakan: pemakaian kateter urin, pemakaian alat intravaskular, transfusi darah, pemasangan selang nasogastrik, pemakaian ventilator dan perawatan luka bekas operasi. Kateterisasi kandung kemih membawa risiko tinggi terhadap infeksi saluran kemih (ISK). Penelitian menunjukkan bahwa 
kebanyakan ISK nosokomial terjadi akibat instrumentasi traktus urinarius, terutama pada tindakan kateterisasi. Pemasangan kateter urin merupakan tindakan perawatan yang sering dilakukan di rumah sakit. Prosedur pemasangan hingga pencabutan kateter urin harus dilakukan sesuai prinsip aseptik untuk mencegah dan mengendalikan ISK nosokomial.

5. Penggunaan antiseptik, penanganan peralatan dalam perawatan pasien dan kebersihan lingkungan. antiseptik dapat digunakan untuk mencuci tangan terutama pada tindakan bedah, pembersihan kulit sebelum tindakan bedah atau tindakan invasif lainnya. (salawati, 2012).

Faktor pelayanan kesehatan dapat diartikan bahwa terjangkaunya pelayanaan kesehatan dan bagaimana kualitas pelayanan kesehatan yang diberikan kepada pasien. Faktor lingkungan berhubungan dengan petugas kesehatan dan pasien dimana petugas kesehatan pemberi pelayanan kesehatan, perawat atau tenaga kesehatan lainnya lebih sering berinteraksi dengan pasien sehingga tenaga kesehatan memiliki peran yang sangat penting bagi pasien, termasuk pengetahuan dari tenaga kesehatan dalam mengidentifikasi tentang infeksi nosokomial, sehingga infeksi nosokomial akan dapat ditangani dengan cepat, sehingga mengurangi angka kejadian infeksi nosokomial di rumah sakit. Rumah sakit harus melakukan tindakan agar dapat mengendalikan angka kejadian infeksi nosokomial sehingga tidak semakin meningkat. Salah satu langka strategi mengendalikan infeksi nosokomial dengan melakukan surveilans (Achmad, 2017).

Menurut Ontario Agency for Health Protection and Promotion (OAHPP) dan Provincial Infectious Diseases Advisory Committee (PIDAC) dan beberapa penelitian, faktor-faktor tersebut terdiri dari:

Faktor luar (extrtinsic factors): Faktor luar berasal dari petugas pelayanan kesehatan, peralatan dan meterial medis, lingkungan, makanan/ minuman, penderita lain, pengunjung/ keluarga. Faktor dari diri pasien (intrinsic factors): Umur, jenis kelamin, kondisi umum pasien, resiko terapi, atau adanya penyakit lain yang menyertai penyakit dasar beserta komplikasinya. Contohnya pada pasien dengan batuk darah (haemoptoe) cenderung akan takut untuk batuk sehingga sisa darah yang ada di saluran nafasnya tidak keluar dan akan mengundang infeksi dengan tidak langsung pasien akan menginfeksi dirinya sendiri.

Faktor keperawatan: lamanya hari perawatan pasien, turunnya standar pelayanan perawatan, serta kepadatan pasien dalam satu ruangan. Faktor mikroba 
patogen: tingakat kemampuan mikroba patogen merusak jaringan, lamanya pemaparan antara sumber penularan dengan pasien.

Selama pengkajian, perawat mengumpulkan temuan objektif, seperti insisi terbuka atau asupan kalori menurun dan data subjektif, seperti keluhan pasien tentang adanya nyeri tekan pada tempat luka infeksi. Kemudian perawat menginterprestasikan data tersebut dengan teliti, mencari kelompok dari karakteristik yang ditetapkan atau faktor risiko yang menciptakan pola yng mengarah pada diagnosa keperawatan. (Potter \& Perry, 1999).

Tenaga kesehatan termasuk perawat wajib menjaga kesehatan dan keselamatan dirinya dan orang lain serta bertanggung jawab sebagai pelaksanaan kebijakan keselamatan dan kesehatan pasien yang telah ditetapkan. Tenaga kesehatan juga bertanggung jawab dalam mengunakan sarana yang telah disediakan dengan baik dan benar serta memelihara sarana agar selalu siap pakai dan dapat dipakai selama mungkin. Dan bertanggung jawab dari segala tindakan yang diberikan kepada pasien.

Tanggung jawab tersebut meliputi:

- Bertanggung jawab melaksanakan dan menjaga kesalamatan kerja dilingkungan. wajib mematuhi intruksi yang dibeikan dalam rangka kesehatan dan keselamatan kerja, dan membantu mempertahankan lingkungan bersih dan aman.

- Mengetahui kebijakan dan menerapkan prosedur kerja, pencegahan infeksi, dan mematuhinya dalam pekerjaan sehari-hari.

- Tenaga kesehatan yang menderita penyakit yang dapat meningkatkan resiko penularan infeksi, baik dari dirinya kepada pasien atau sebaliknya, sebaiknya tidak merawat pasien secara langsung atau dapat menggunakan pelindung seperti masker.

- Bagi tenaga kesehatan yang megidap HIV mempunyai kewajiban moral untuk memberi tahu atasannya tentang status serologi bila dalam pelaksanaan pekerjaan status serologi tersebut dapat menjadi resiko pada pasien.

Aspek pengukuran dengan menggunakan kuesioner. Kuesioner pengukuran pengetahuan bidan menggunakan multiple choice dan pengukuran tindakan pencegahan infeksi menggunakan dicotomi dengan jumlah. Metode analisis data yang digunakan adalah analisis Univariat dan Bivariat. Dimana analisis Univariat untuk mengetahui distribusi frekuensi, dan persentase dari masing-masing variabel bebas dan variabel terikat. Analisis Bivariat untuk mengetahui hubungan antara variabel bebas dan terikat dengan menggunakan uji statistik Rank Spearman (Aziz, 2017). 
Beberapa prinsip dasar yang penting dalam kriteria infeksi nosokomial adalah informasi yang digunakan untuk menentukan adanya infeksi yang diklassifikasi berdasar kombinasi antara hasil pemeriksaan klinis dan hasil pemeriksaan laboratorium atau tes-tes lainnya. Bukti klinis adanya infeksi didapat dari observasi langsung pada lokasi infeksi pada pasien atau dari sumber-sumber data yang lain, misalnya dari status pasien. Bukti laboratorium adalah hasil biakan, tes deteksi antigen atau antibodi, atau visualisasi mikroskopis (Ibrahim, 2019).

\section{PENUTUP}

Dihapkan bagi perawat untuk meningkatkan pengetahuan dan pelaksanan hand hygiene melalui program pelatihan pengurangan infeksi agar angka kejadian infeksi nosokomial semakin berkurang.

Infeksi nosokomial ini dapat dicegah apabila petugas selalu melakukan proses keperawatan sesuai standar praktik keperawatan. Upaya untuk mencegah terjadinya infeksi nosokomial adalah dengan selalu mencuci tangan sebelum melakukan tindakan, menggunakan alat pelindung diri, praktik keselamatan pasien, perawatan pasien dan penggunaan antiseptik. Banyak faktor yang menyebabkan terjadinya infeksi yaitu faktor instrinsik dan ekstrinsik.

\section{DAFTAR PUSTAKA}

Hapsari, P.A., C.U., dkk. (2018). Pengetahuan Petugas Surveilans Tentang Identifikasi HealthcareAssociated Infections Di Surabaya. Jurnal Berkala Epidemiologi, 6(2), 130-138.

DOI:

10.20473/jbe.v6i22018.130-138

Marfu'ah, S., Sofiana, L. (2018). Analisis tingkat kepatuhan hand hygiene perawat dalam pencegahan infeksi nosokomial. Jurnal Fakultas Kesehatan Masyarakat.12(1).

Nurseha, Djaafar. (2013). Pengembangan Tindakan Pencegahan Infeksi Noaokomial Oleh Perawat di Rumah Sakit Berbasis Health Belief Model. Jurnal Ners. 8(1):64-71.

Purwantiningsih, S. 2014. Hubungan Tingkat Pengetahuan dan Sikap Petugas Kesehatan dengan Penerapan Teknik Mencuci Tangan Secara Benar. [serial online Diakses dari URL:http://digilib.stikeskusumahusa da.ac.id/files/disk1/23/01gdlsripurwant.

Rahmawati, R. 2014. Pengetahuan dan Sikap Perawat Pencegahan Infeksi Nosokomial dalam Pelaksanaan Cuci Tangan. [serial online] Diakses dari URL: 
http://journal.unigres.ac.id/inde

x.php/JNC/article/download/106/104

Riyani., syafriani. (2019). Hubungan

Antara Motivasi Dengan Kepatuhan

Perawat Melaksanakan Handhygiene

Sebagai Tindakan Pencegahan

Infeksi Nosokomial Di Ruang Rawat

Inap Rumah Sakit Ah Tahun 2019.

Jurnal Ners Research \& Learning In

Nursing Science. 3(2). 49-59.

Rosaliya, yosi et all.,(2012). Faktor Faktor

yang Mempengaruhi Kejadian

Infeksi Nosokomial pada Pasien

Luka Post Operasi di RSUD Tugurejo

Semarang. Stikes Tugurejo. Program

Studi Ilmu keperawatan.

Safiya, I.F., \& Putra, A. (2019). Hubungan

Pengetahuan Dengan Sikap Perawat

Dalam Penerapan Hand Hygiene Di

Ruang Rawat Inap Medikal Bedah

Rumah Sakit. JIM Fkep. 4(1). 152154.

Salawati, Liza, (2012). Pengendalian Infeksi Nosokomial di Ruang Intensif Care Unit Rumah Sakit. Jurnal Kedokteran Syiah Kuala. 12(1):4752.

Simamora, R. H. (2019). Menjadii Perawat yang: CIH'HUY. Surakarta: Kekata Publisher.
Simamora, R. H. (2017). A strengthening of role of health cadres in BTA-Positive Tuberculosis (TB) case invention through education with module development and video approaches in Medan Padang bulan Comunity Health Center, North Sumatera Indonesia. International Journal of Applied Engineering Research, 12(20), 10026-10035.

Simamora, R. H., \& Saragih, E. (2019). Penyuluhan kesehatan terhadap masyarakat: Perawatan penderita asam urat dengan media audiovisual. JPPM (Jurnal Pendidikan dan Pemberdayaan Masyarakat), 6(1), 24-31.

Waney, M.P. 2016. Faktor-Faktor yang Berhubungan dengan Penerapan Hand Hygiene di Instalasi Rawat Inap Rumah Sakit Tingkat III R. W. Mongisidi Manado [serial online]. Diakses dari URL: https://ejournalhealth.com/index.php /CH/article/view/107

Zulkarnain. (2018). Analisis hubungan perilaku perawat terhadap tindakan pencegahan infeksi nosokomial (phelibitis) di Ruang Perawatan Interna RSUD Bima tahun 2018. JI

SIP, 2(1). 